\title{
The Study of Inorganic Ion Composition and Chemical Properties of Rain Water Over Tehran City
}

\section{DINA ABDEMANAFI' ${ }^{1 *}$, AMIR-HUSSAIN MESHKATEE'1, SOHRAB HAJJAM ${ }^{1}$ and MAJID VAZIFEDOUST ${ }^{2}$}

\author{
'Department of Meteorology, College of Basic Sciences, \\ Tehran Science and Research Branch, Islamic Azad University, Tehran, Iran. \\ ${ }^{2}$ Water Engineering Department, faculty of agricultural sciences, University of Guilan, Iran. \\ ${ }^{*}$ Corresponding Author E-mail : dina_ai@yahoo.co.uk \\ http://dx.doi.org/10.13005/ojc/320141
}

(Received: January 07, 2016; Accepted: February 24, 2016)

\begin{abstract}
Concentrations of major inorganic ions $\left(\mathrm{NH}_{4}, \mathrm{Mg}, \mathrm{SO}_{4}, \mathrm{NO}_{3}, \mathrm{NO}_{2}, \mathrm{Na}, \mathrm{Ca}, \mathrm{HCO}_{3}, \mathrm{~F}, \mathrm{Cl}, \mathrm{Br}, \mathrm{K}\right)$, PH, Total Dissolved Solids (TDS), Electrical Conductivity (EC), Total Alkalinity and Total Hardness in bulk precipitation samples collected in the Tehran city of I.R. of Iran were analyzed. Results show that concentrations of the found substances were higher over the Mehrabad station. The mean concentration of ions indicated that, $\mathrm{HCO}_{3}, \mathrm{SO}_{4}$ and $\mathrm{NO}_{3}$ and were the main anions, while $\mathrm{Ca}, \mathrm{Na}, \mathrm{NH}_{4}$ and $\mathrm{Mg}$ were the main cations. Measured $\mathrm{PH}$ had shown that autumn and winter precipitation were mostly acidic while the spring and summer were mostly alkaline. The $\mathrm{pH}$ ranged from 4.6 to 8.1 with a mean of 6.3. The alkaline cations $\mathrm{Ca}$ and $\mathrm{Mg}$ and also Bicarbonate anion acted as acid neutralizers and buffered the acidity of rain. The Bicarbonate anion had the highest concentration, among all other ions, over both stations and plays an important role in reduction of the acidity of the rain water. Study upon the potential sources of the ions over Tehran by means of Correlation Analysis, Enrichment Factor and Principle Component Analysis indicate that existence of Qom salt lake and desert in the south of the city were the main source of the $\mathrm{Ca}, \mathrm{Mg}, \mathrm{K}$ and $\mathrm{Na}$. There are anthropogenic sources for $\mathrm{SO}_{4}, \mathrm{NO}_{3}, \mathrm{NO}_{2}, \mathrm{~F}, \mathrm{Br}$ ion's. The other ions $\mathrm{HCO}_{3}$ and $\mathrm{NH}_{4}$ were from anthropogenic and dust origin.
\end{abstract}

Keyword: Air pollution; Precipitation; Scavenging; Source assessment; chemistry.

\section{INTRODUCTION}

Precipitation is one of the most efficient mechanisms for washing the atmospheric pollutants, specifically particulate ones out. The process has two very important consequences (one good and one bad). The good one is that it clears atmosphere from many substances that have adverse impacts on many aspects of life whereas the bad one is that their reaction with rain water leads to the formation of some dangerous and destructive substances that have great impacts on both, the natural environment as well as manmade constructions. Precipitation chemistry plays an important role in 
understanding the air quality in a study area, because the concentrations and distribution of chemical components in rain depend on a variety of emission sources.

Realizing that, a lot of effort has been made in order to identify the nature and type of those particulates, especially in urban environment ${ }^{1-12}$. Study upon the atmospheric pollutants and their nature in Tehran atmosphere goes back to 1991, when Ismaeili Sari², initially attempted to identify the nature of atmospheric pollutants over Tehran by sampling rain waters from synoptic and climatology stations (also, he did the same research for one station in Tehran ${ }^{3}$. The results for two researches have shown and also compared with present study in the section of results and discussion.

The city of Tehran (figure 1), the capital of I. R. of Iran is a mega-polis with more than 10 million population. The growth of the city during the last 30 years has turned the city to one of the most polluted cities in the country particularly during the autumn and winter. The geographical conditions of the city are the other most important factor affecting the city environmental condition and the nature of the particles that may be found in its atmosphere. The city long term annual average precipitation is $300 \mathrm{~mm}$. It receives its precipitation mainly during autumn, winter (the most polluted period of the year) and spring. Consequently, understanding the impact of matter and substances that enter into the Tehran atmosphere on the precipitation is very important. Tehran is located in the south foot of central part of Alborz mountain range, where the height range varies between 2000 and $4000 \mathrm{~m}$ above mean sea level. Tehran is one of the industrialized cities of the country. Factories and industrial units are mainly located in southwest and east of the city. Tehran is also located in northern outskirt of Iran central desert. There is a salt lake in the south of the city called Qom salt lake that is the end rout of some main streams in the central part of the Alborz mountain range. Due to the impact of the climate change, dam construction on those rivers and extensive water usage, the lake is almost dry for a substantial proportion of the year. The city, also, ends to a plain on its northeastern part. Tehran rainy season starts at the middle of the autumn and ends in the middle of the spring. This does not mean there is no precipitation occurrence during other parts of the year, but if it rains it will not be that significant and it is mostly a trace.

Despite the fast city growth and significant increase in the number of the motor vehicles since those studies, no other study has been done to examine the impact of these two factors on the nature and concentration of the atmospheric pollutants over the city. This study aimed to provide a detailed evaluation of the chemical composition of precipitation in the Tehran and to evaluate the relative contributions of various sources.

\section{Data and Methodology \\ Sampling Sites and Sample Analysis}

In this article, two Mehrabad and Aghdasiyeh synoptic stations were selected for rain water sampling. Aghdasiyeh synoptic station started to work in 1988 and is located in the northeast of Tehran, the area with highest annual average of precipitation among other areas of the city. According to Iranian Meteorological Organization records, the annual average of precipitation in this area is $420 \mathrm{~mm}$. Mehrabad synoptic station is the oldest meteorological station of the city that started to work in 1951 and is located in Mehrabad airport at the west of Tehran. Considering the distribution of the industrial units and factories, buildup areas, aerial and ground traffics and transportations, local daily atmospheric circulation, and the geographical location of the station, it could be claimed that the station is prone to substantial periods of air pollution from both natural and anthropogenic sources. The annual average of precipitation over this station is $231 \mathrm{~mm}$. Figure1 and table 1, gives information about the geographical location of the two stations relative to the city.

Rain water samples were collected manually. The rain water collectors were located at $1.5 \mathrm{~m}$ height above the roof of the two stations' buildings. To avoid any unwanted contamination of collected samples all bottles were washed with washing liquid, then strained six times by distilled water and finally drained by de-ionized water with electrical conductivity of less than $1.5 \mathrm{is} / \mathrm{cm}$. Each sampling started at the time of the onset of each rainfall event. Then, the collected water transferred to glass bottles and was sent to the laboratory in less than 24 hours. The samples were kept in temperatures ranging from 2 to $4^{\circ} \mathrm{C}$ during 
transfer to the laboratory. Sampling was taken place in autumn, winter and spring in the year of 2012 and 2013 as well as summer and autumn in the year of 2015. In total, 30 samples from the two stations were sent to laboratory for carrying out the analysis.

Samples anions and cations were measured by the Ion Chromatograph model 850 from MetrohmCompany and their $\mathrm{pH}$ and $\mathrm{EC}$ (in $\mu \mathrm{s} / \mathrm{cm}$ ) were measured by Multi-HQ40d. Bicarbonate and carbonate anions were calculated relative to methyl orange. TDS was calculated from the equation below (1):

$\operatorname{TDS}(\mathrm{ppm})=\frac{\text { final weight of residues }(\mathrm{mg}) \times 1000}{\text { initial sample volume in } \mathrm{ml}}$

\section{Source assessment}

In this article, Enrichment Factors, Correlation Analysis and Principal Component Analysis had been used in order to identify the sources of ions found in sampled rain waters.
Since the early 1970's a factor called Enrichment Factor (EF) is being used to identify the source(s) of substances that are found in the atmosphere or water. Many authors used this factor to identify the source(s) of ions that had been found in the rain water ${ }^{13-18}$. Rahn (1975) ${ }^{19}$ introduced equation (2) for calculating EF for rain water.

$$
E F(X)=\frac{\frac{X}{(\text { Ref })_{\text {aerosol }}}}{\frac{X}{(\text { Ref })_{\text {source }}}}
$$

Where, $\mathrm{X}$ is the under study substances concentration and Ref stands for reference. Normally sodium is taken as reference aerosol for seawater and aluminium or calcium is taken as reference aerosol for land. Since there was not any aluminium among the identified substances in sampled rain water, calcium was used as reference aerosol. Equation 3 and 4 were used for the calculation of EF's for marine and land environments ${ }^{10 ; 11 .}$

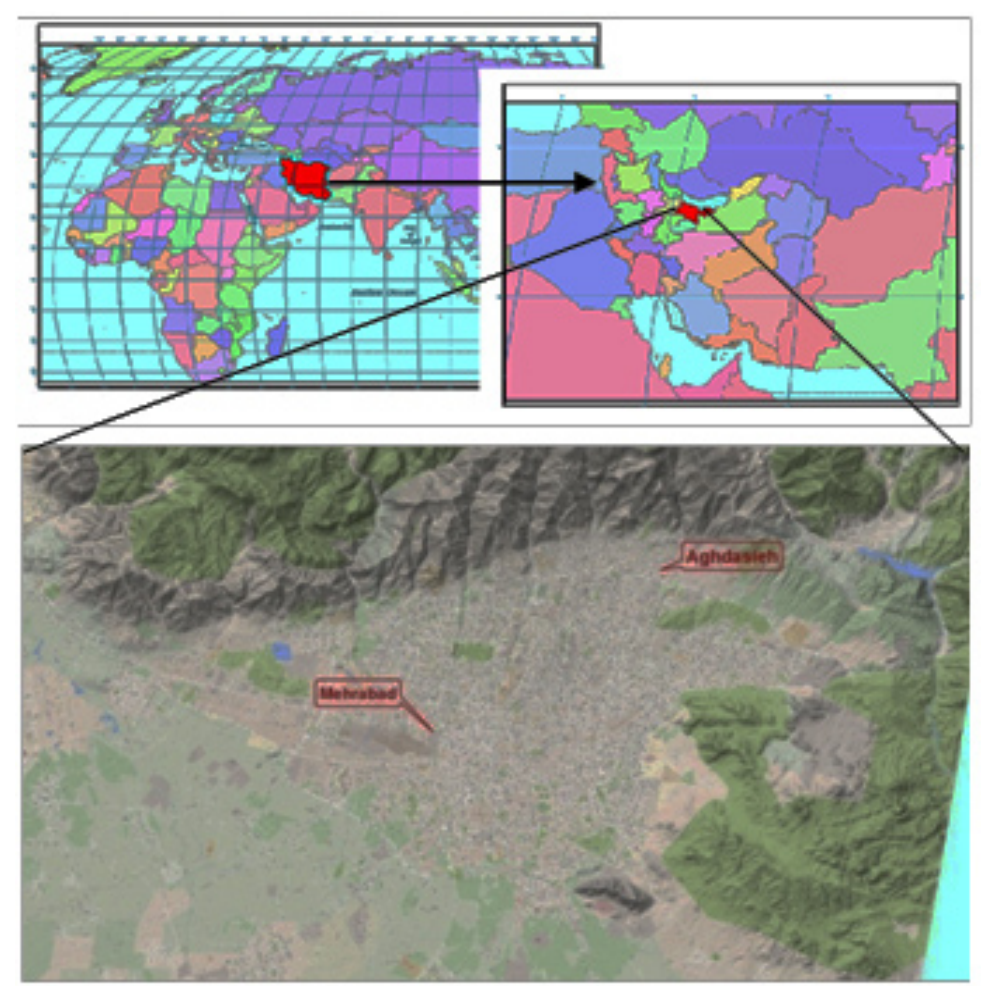

Fig. 1: Locations of the study area and sampling stations 
$\mathrm{EF}(\mathrm{X})=\frac{\left(\frac{\mathrm{X}}{\mathrm{Na}}\right)_{\text {rain water }}}{\left(\frac{\mathrm{X}}{\mathrm{Na}}\right)_{\text {Marine }}}$

$\mathrm{EF}(\mathrm{X})=\frac{\left(\frac{\mathrm{X}}{\mathrm{Ca}}\right)_{\text {rain water }}}{\left(\frac{\mathrm{X}}{\mathrm{Ca}}\right)_{\text {soil }}}$

To calculate EF's, denominators were adopted from Keene et al., (1986) ${ }^{14}$ and Taylor (1964) 20 for marine and land environments, respectively.

If $E F$ is near one it means the enrichment has happened by that source (sea or land). EFs higher than one indicate that the source(s) was somewhere else.

Another methods that had been used by some authors to identify the sources of ions found in sampled rain waters was Correlation Analysis and Principal Component Analysis which were both used in this paper $21 ; 10 ; 22 ; 18 ; 23$.

\section{RESULTS AND DISCUSSIONS}

\section{Physiochemical properties of rain water}

Table 2 parts $a$ and $b$ show the volumeweighted mean, Volume-weighted standard deviation, minimum and maximum of $\mathrm{PH}$, Total Alkalinity, EC, TDS and Total Hardness for both the Aghdasieh and Mehrabad stations. To calculate volume-weighted averages and standard deviations formulas 5 and 6 were used ${ }^{24 ; 21}$

$\overline{V W M}=\frac{\sum_{i=1}^{N} X_{i} p_{i}}{\sum_{i=1}^{N} p_{i}}$

$V W S D=\left(\left(\frac{\mathrm{N} \sum_{\mathrm{i}=1}^{\mathrm{N}} \mathrm{p}_{\mathrm{i}}^{2} \mathrm{x}_{\mathrm{i}}^{2}-\left(\left(\sum_{\mathrm{i}}^{\mathrm{N}} \mathrm{x}_{\mathrm{i}} \mathrm{p}_{\mathrm{i}}\right)\right)^{2}}{\left(\sum_{\mathrm{i}}^{\mathrm{N}} \mathrm{p}_{\mathrm{i}}\right)^{2}(\mathrm{~N}-1)}\right)\right)^{\frac{1}{2}}$

where $\mathrm{P}_{\mathrm{i}}, \mathrm{X}_{\mathrm{i}}$, and $\mathrm{N}$ are precipitation amount and entity concentration for $\mathrm{i}^{\text {th }}$ sample and number of samples, respectively. Results show that in Aghdasieh the lowest measured $\mathrm{pH}$ was 4.72 and the highest was 7.95. The highest calculated Alkalinity was 33.58ppm. The same studies for Mehrabad

Table1: Characteristics of sampling stations in the Tehran

\begin{tabular}{lcccc}
\hline Station Name & Latitude & Longitude & Elevation(M) & Description \\
\hline Mehrabad & $35^{\circ} 41^{\prime}$ & $51^{\circ} 19^{\prime}$ & 1190.8 & Urban(airport) \\
Aghdasieh & $35^{\circ} 47^{\prime}$ & $51^{\circ} 37^{\prime}$ & 1548.2 & Urban \\
\hline
\end{tabular}

\section{Mean for differ ent seasons}

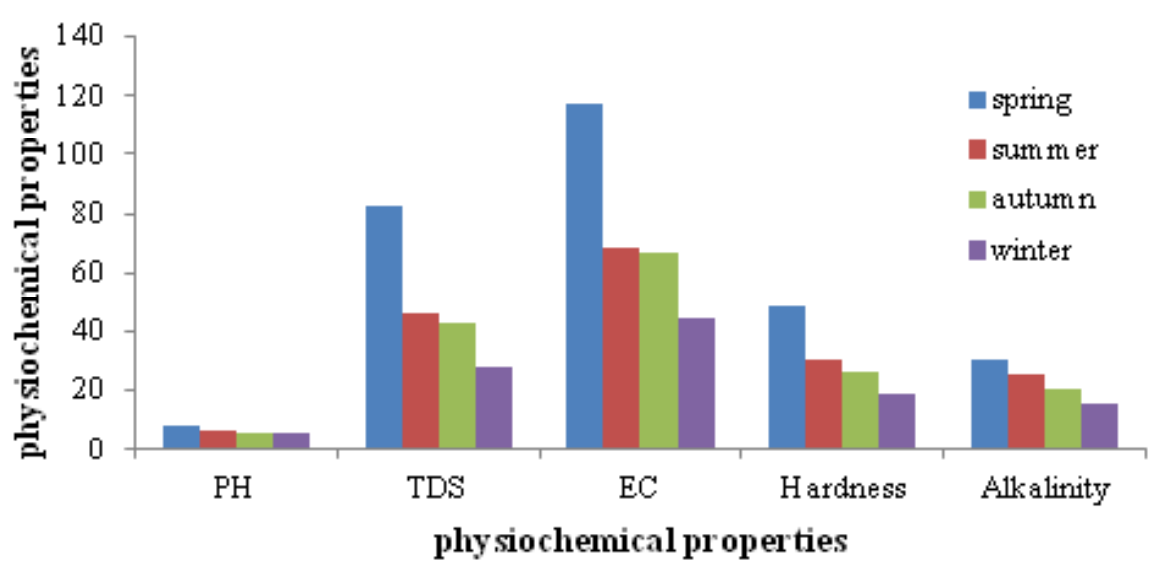

Fig. 2: Mean of physiochemical properties for different seasons and for both stations (Mehrabad and Aghdasieh) 


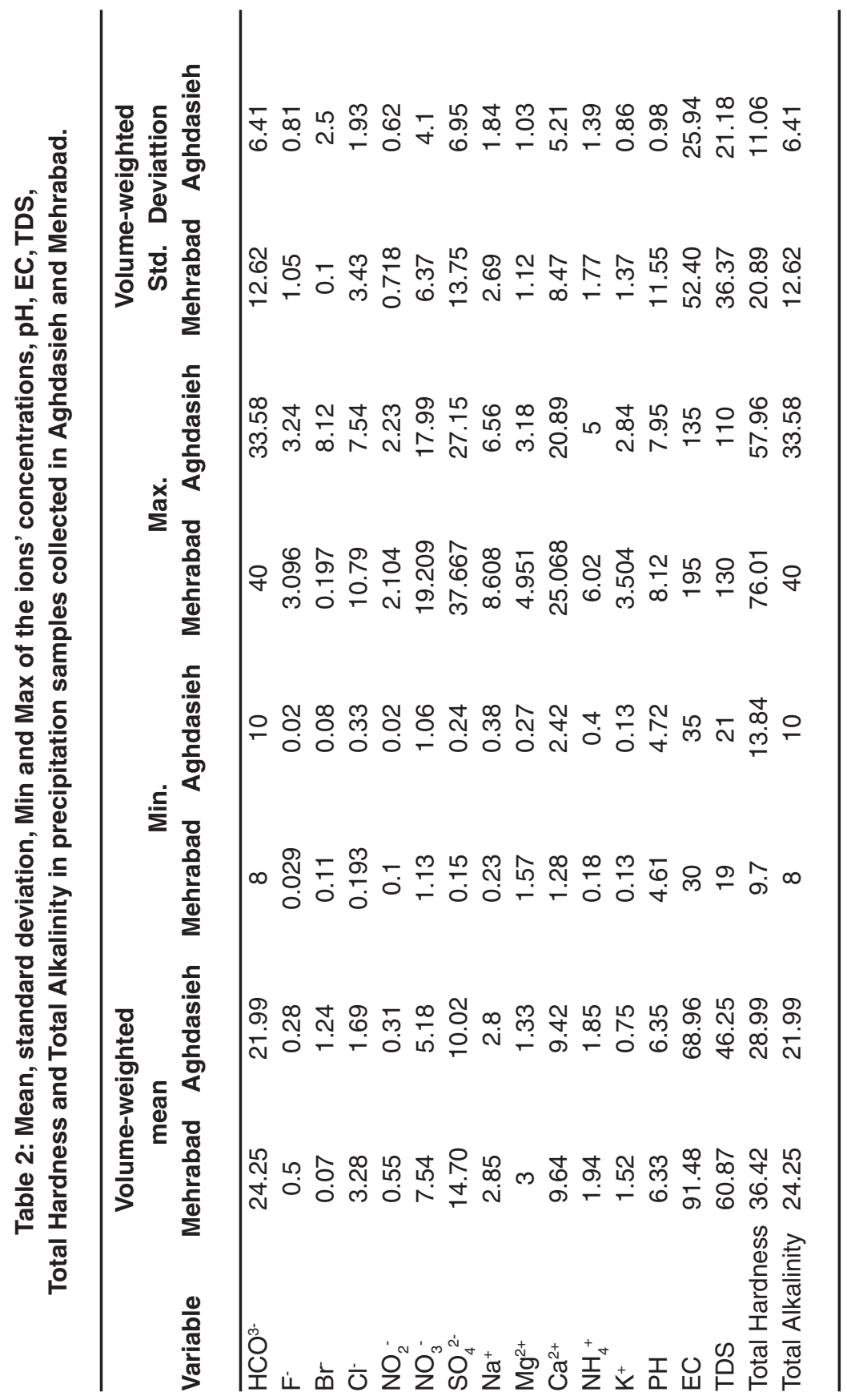


indicate that the lowest and highest measured $\mathrm{pH}$ were 4.61 and 8.12, respectively. Again, the highest calculated Alkalinity was 40ppm. EC, TDS and Total Hardness were slightly higher at Mehrabad than Aghdasieh. They were 135ìs/cm, 110ppm, and 57.95ppm in Aghdasieh and 195ìs/cm, 130ppm, and $76.01 \mathrm{ppm}$ in Mehrabad, , respectively.

In figure 2, the mean of $\mathrm{pH}, \mathrm{EC}, \mathrm{TDS}$, Total Alkalinity and Total Hardness of rain water samples in

\section{Mean for different seasons}

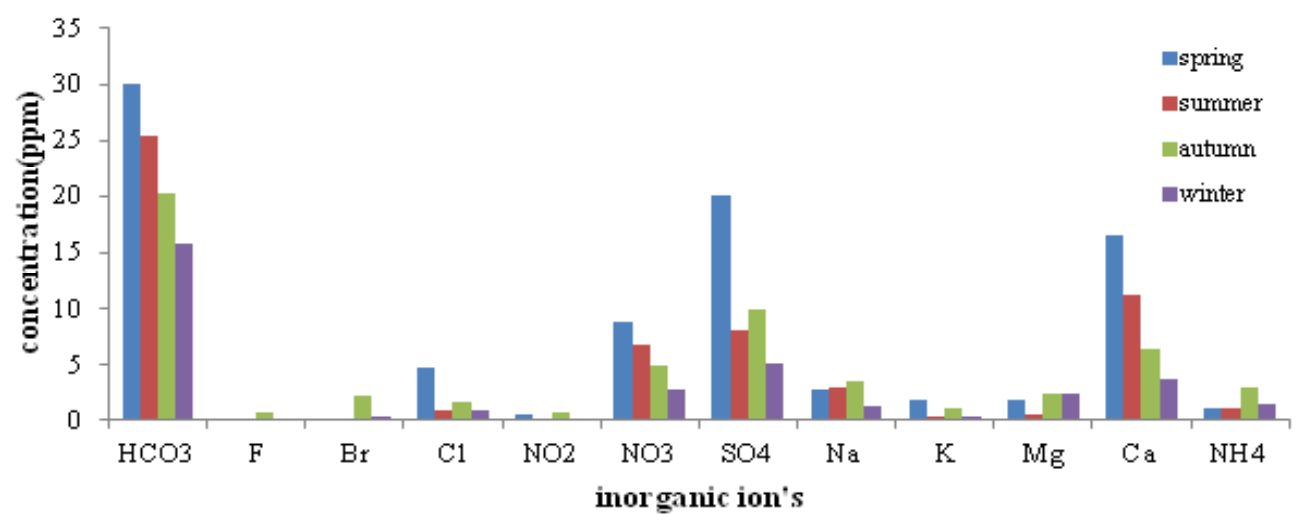

Fig. 3: Mean of concentration inorganic ion's for different seasons and for both stations (Mehrabad \& Aghdasieh)
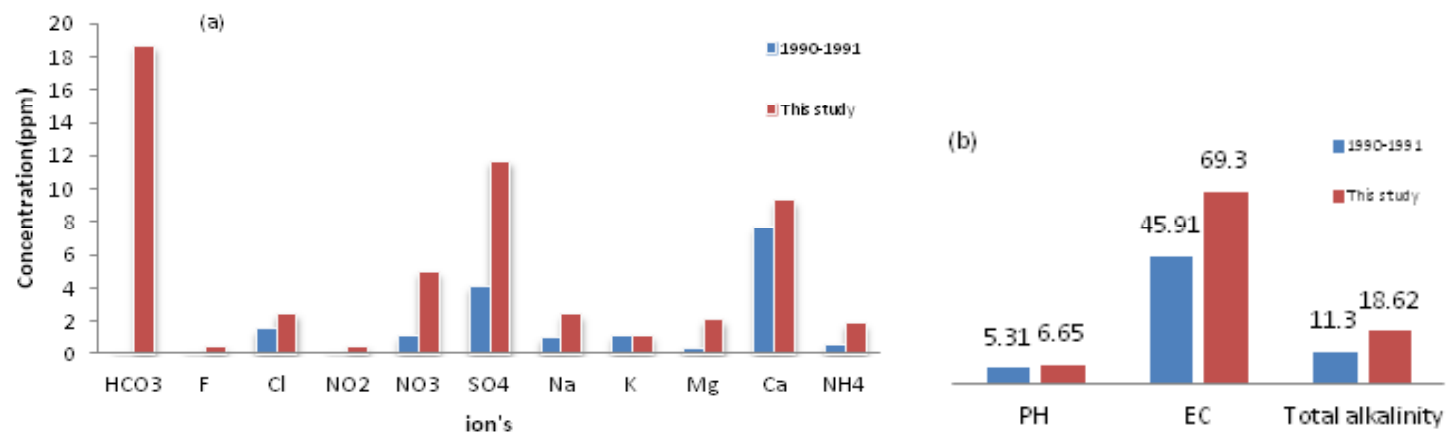

Fig. 4: Compares (a) the mean concentration of different ions that were found in sampled rain waters in Aghdasieh station (1990-1991(blue), this study (red)) and (b) Means of pH, EC and Total alkalinity of rain water in Aghdasiyeh station (1990-1991(blue), this study (red))

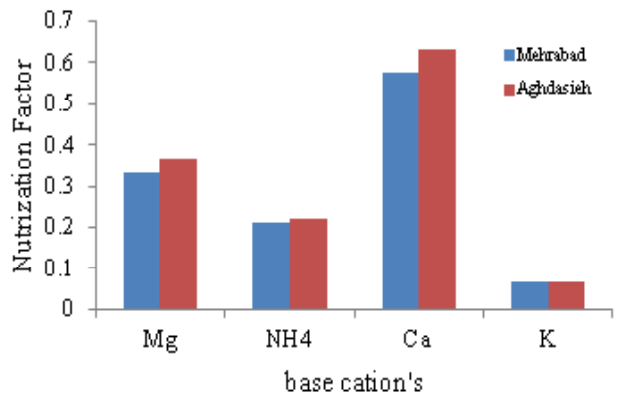

Fig. 5: Average Neutralization factors of base cation's $\mathrm{Ca}^{2+}, \mathrm{NH}_{4}^{+}, \mathrm{K}^{+}, \mathrm{Mg}^{2+}$ in Tehran (Aghdasieh \& Mehrabad) different seasons of year and for both stations were shown. Results show that all of the values were the highest in spring and the lowest in winter.

\section{Major inorganic ion}

$\mathrm{NH}_{4}^{+}, \mathrm{Mg}^{2+}, \mathrm{SO}_{4}^{2-}, \mathrm{NO}_{3}^{-}, \mathrm{NO}_{2}^{-}, \mathrm{Na}^{+}, \mathrm{Ca}^{2+}, \mathrm{HCO}_{3}^{-}$ $, \mathrm{F}^{-}, \mathrm{Cl}^{-}, \mathrm{Br}^{-}$and $\mathrm{K}^{+}$major Anions and Cations were found in the sampled rain waters. Tables $2 a$ $a n d b$ are showing the mean, max, min and standard deviation of inorganic major ions concentration. Volume-weighted mean and Volume-weighted standard deviation that are calculated from relations 
5 and 6 . The results indicate that concentration of all ions were higher in Mehrabad samples than Aghdasieh samples. At both sites, bicarbonate had the highest contribution in the total ion concentration by $35 \%$. Sulfate, calcium and nitrate were the next high concentration contributors in the total concentration of ions by 22, 14 and 10 percents, respectively. Another interesting result of the examination of the chemical combination of sampled rain waters was the absence of carbonate among the found ions.

In figure 3, the mean of inorganic ion concentrations of rain water samples in different seasons of year and for both stations were shown. The results in figure (2) and (3), had shown that high concentrations of bicarbonate anion and calcium cation in rain water samples is probably the main cause of observed alkalinity durina spring. The main source of those substances is ${ }^{\mathrm{CO}_{2}}$ gas and earth's crust. According to Pruppacher and Klett (1997) ${ }^{25}$ dusts are effective ice nuclease. However, they may effectively incorporate in the formation of rain droplets if sulfate aerosols sediment on them ${ }^{26 ; 27 ; 28}$. This process may be considered possible, especially, in winter time, when the number of sources for sulfur dioxide emission increases significantly. Due to high concentrations of sulfate anion and calcium cation in the spring, this will prove that this is true.

To investigate whether there are some differences between this and the two other studies that had been made by Esmaeili Sari et al. in 1991 and $1997^{2 ; 3}$ the results were compared (Figure 4-a \& 4-b). One of the most important results of this comparison is the observed trend of precipitation towards alkalinity since the study of Esmaeili Sari et al. $(1991,1997)^{2 ; 3}$. Two reasons may be given for the observed trend. First, Esmaeili Sari et al. (1997) ${ }^{3}$ study was carried out in the occasion of Iraq war on Kuwait and burning of the oil fields that emitted huge amount of sulfur dioxide in to atmosphere and second, is the impact of climate change that resulted in the longer dry period in Iran. The latter resulted in higher concentration of cations like calcium and magnesium and bicarbonate anion in the Tehran atmosphere due to more effective wind erosion of surface soils around Tehran as well as rise in the concentration observed for other anions and cations. Considering the main sources of those anions and cations their concentration increase could be attributed to the city population and area growth that inevitably led to a higher emission of particulate and gaseous pollutants into the city atmosphere.

\section{Acid Neutralization}

Acids are neutralized by bases such as $\mathrm{NH}_{3}$, anions (oxides, carbonates, or bicarbonates, etc.) and base cations like $\mathrm{Ca}^{2+}, \mathrm{Mg}^{2+}, \mathrm{K}^{+}, \mathrm{NH}_{4}^{+}$, etc. Neutralization of the acids by these base cations was obtained by calculating the Neutralization Factor (NF) that had been introduced by Kulshrestha at al. in 1995:

$\mathrm{NF}_{\mathrm{X}}=\frac{\mathrm{X}}{\left(\mathrm{NO}_{3}+\mathrm{SO}_{4}\right)}$

Table 3: Enrichment factors relative to seawater for rainwater constituents in Tehran (Aghdasieh\& Mehrabad)

\begin{tabular}{ccccccc}
\hline EF marine & $\mathbf{K}^{+}$ & $\mathbf{C a}^{2+}$ & $\mathbf{M g}^{2+}$ & $\mathbf{C l}^{-}$ & $\mathbf{S O}_{4}{ }^{2-}$ & $\mathbf{N O}_{3}{ }^{-}$ \\
\hline Mehrabad & 24.227 & 76.863 & 4.634 & 0.991 & 41.256 & 132250 \\
Aghdasieh & 21.361 & 72.431 & 3.814 & 0.879 & 38.896 & 103500 \\
\hline \multicolumn{7}{c}{ Table 4: Enrichment factors relative to soil for rainwater } \\
constituents in Tehran (Aghdasieh\& Mehrabad) \\
\hline EF soil & $\mathbf{K}^{+}$ & $\mathbf{N a}^{2+}$ & $\mathbf{M g}^{2+}$ & $\mathbf{C l}^{-}$ & $\mathbf{S O}_{4}{ }^{2-}$ & $\mathbf{N O}_{3}^{-}$ \\
\hline Mehrabad & 0.311 & 0.518 & 0.554 & 109.677 & 81.06 & 372.38 \\
Aghdasieh & 0.191 & 0.55 & 0.483 & 103.225 & 81.117 & 309.04 \\
\hline
\end{tabular}


Where, $\mathrm{X}$ is the cation concentration ${ }^{21}$; 10; 29. The average neutralization effect of basic cations identified in the samples, i.e. $\mathrm{Ca}^{2+}, \mathrm{Mg}^{2+}, \mathrm{K}^{+}$and $\mathrm{NH}_{4}^{+}$for both sites are shown in Figure(5). Figure5 indicates that Calcium was the main neutralizer and Potassium's role in neutralization was less than the other basic cations. Another conclusion that could be made is that because of the higher NF for all cations but Potassium at Aghdasieh, it could be expected that whenever taking a sample of rainfall in this site, it would be less acidic than samples collected in
Mehrabad. The $\mathrm{pH}$ measurements also, confirm this result. The soil texture in the northeastern part of the city that is calcium reached, confirm the result, too (see http://www.ime.org.ir for more details).

\section{Enrichment Factor}

Results of the calculation of EnrichmentFactor (EF) for $\mathrm{SO}_{4}^{2-}, \mathrm{Ca}^{2+}, \mathrm{Mg}^{2+}, \mathrm{K}^{+}, \mathrm{Cl}^{-}$by equation 3 and for $\mathrm{SO}_{4}^{2-}, \mathrm{Mg}^{2+}, \mathrm{K}^{+}, \mathrm{Na}^{+}, \mathrm{NO}_{3}, \mathrm{Cl}^{-}$ by equation 4 are presented in tables 3 and 4 . According to the results, $\mathrm{Cl}^{-}$at both stations had roots in marine sources and magnesium came from

Table5: Matrix of Pearson correlation coefficients for major

(a) Aghdasieh ions and pH in (a)Aghdasieh, (b)Mehrabad stations

\begin{tabular}{|c|c|c|c|c|c|c|c|c|c|c|c|c|c|}
\hline & PH & $\mathrm{HCO}_{3}^{-}$ & $F^{-}$ & $\mathrm{Cl}^{-}$ & $\mathrm{Br}$ & $\mathrm{NO}_{2}^{-}$ & $\mathrm{NO}_{3}^{-}$ & $\mathrm{SO}_{4}{ }^{2-}$ & $\mathrm{Na}^{+}$ & $\mathrm{Mg}^{2+}$ & $\mathrm{Ca}^{2+}$ & $\mathrm{NH}_{4}^{+}$ & $\mathbf{K}^{+}$ \\
\hline $\mathrm{PH}$ & 1 & & & & & & & & & & & & \\
\hline $\mathrm{HCO}_{3}^{-}$ & 0.056 & 1 & & & & & & & & & & & \\
\hline $\mathrm{F}^{-}$ & 0.104 & -0.532 & 1 & & & & & & & & & & \\
\hline $\mathrm{Cl}^{-}$ & 0.577 & -0.361 & 0.435 & 1 & & & & & & & & & \\
\hline $\mathrm{Br}$ & -0.012 & 0.637 & 0.105 & 0.182 & 1 & & & & & & & & \\
\hline $\mathrm{NO}_{2}^{-}$ & 0.393 & -0.693 & 0.939 & 0.959 & -0.148 & 1 & & & & & & & \\
\hline $\mathrm{NO}_{3}^{-}$ & 0.431 & 0.122 & -0.112 & 0.708 & 0.014 & -0.120 & 1 & & & & & & \\
\hline $\mathrm{SO}_{4}^{2-}$ & 0.695 & -0.043 & -0.127 & 0.651 & 0.421 & 0.165 & 0.668 & 1 & & & & & \\
\hline $\mathrm{Na}^{+}$ & 0.241 & 0.487 & -0.303 & -0.011 & 0.767 & -0.2 & 0.247 & 0.418 & 1 & & & & \\
\hline $\mathrm{Mg}^{2+}$ & 0.022 & -0.823 & 0.518 & 0.349 & -0.342 & 0.696 & -0.131 & 0.114 & -0.271 & 1 & & & \\
\hline $\mathrm{Ca}^{2+}$ & 0.432 & 0.575 & -0.338 & 0.376 & 0.564 & -0.450 & 0.729 & 0.640 & 0.359 & -0.587 & 1 & & \\
\hline $\mathrm{NH}_{4}^{+}$ & -0.266 & -0.465 & -0.106 & -0.132 & 0 & -0.007 & -0.012 & 0.285 & 0.5 & 0.617 & -0.225 & 1 & \\
\hline $\mathrm{K}^{+}$ & 0.628 & -0.303 & -0.078 & 0.576 & -0.196 & 0.271 & 0.488 & 0.799 & 0.443 & 0.375 & 0.177 & 0.522 & 1 \\
\hline
\end{tabular}

(b) Mehrabad

\begin{tabular}{|c|c|c|c|c|c|c|c|c|c|c|c|c|c|}
\hline & PH & $\mathrm{HCO}_{3}^{-}$ & $F^{-}$ & $\mathrm{Cl}^{-}$ & $\mathrm{Br}$ & $\mathrm{NO}_{2}^{-}$ & $\mathrm{NO}_{3}^{-}$ & $\mathrm{SO}_{4}{ }^{2-}$ & $\mathrm{Na}^{+}$ & $\mathbf{M g}^{2+}$ & $\mathrm{Ca}^{2+}$ & $\mathrm{NH}_{4}^{+}$ & $\mathbf{K}^{+}$ \\
\hline $\mathrm{PH}$ & 1 & & & & & & & & & & & & \\
\hline $\mathrm{HCO}_{3}^{-}$ & 0.718 & 1 & & & & & & & & & & & \\
\hline $\mathrm{F}^{-}$ & 0.06 & -0.15 & 1 & & & & & & & & & & \\
\hline $\mathrm{Cl}^{-}$ & 0.77 & 0.65 & 0.072 & 1 & & & & & & & & & \\
\hline $\mathrm{Br}$ & -0.21 & -0.44 & -0.34 & -0.44 & 1 & & & & & & & & \\
\hline $\mathrm{NO}_{2}^{-}$ & 0.185 & 0.365 & 0.90 & 0.36 & -0.48 & 1 & & & & & & & \\
\hline $\mathrm{NO}_{3}^{-}$ & 0.45 & 0.22 & 0.5 & 0.75 & -0.57 & 0.78 & 1 & & & & & & \\
\hline $\mathrm{SO}_{4}^{2-}$ & 0.46 & 0.083 & -0.3 & 0.4 & -0.35 & -0.003 & 0.44 & 1 & & & & & \\
\hline $\mathrm{Na}^{+}$ & 0.055 & 0.282 & -0.123 & 0.282 & -0.342 & 0.162 & 0.419 & 0.79 & 1 & & & & \\
\hline $\mathrm{Mg}^{2+}$ & -0.11 & 0.05 & 0.74 & 0.05 & -0.38 & 0.84 & 0.66 & 0.07 & 0.26 & 1 & & & \\
\hline $\mathrm{Ca}^{2+}$ & 0.87 & 0.86 & -0.22 & 0.86 & -0.27 & 0.02 & 0.51 & 0.55 & 0.14 & -0.16 & 1 & & \\
\hline $\mathrm{NH}^{4+}$ & -0.25 & -0.22 & 0.1 & -0.22 & 0.24 & 0.13 & 0.18 & 0.68 & 0.76 & 0.52 & -0.2 & 1 & \\
\hline $\mathrm{K}^{+}$ & 0.44 & 0.67 & 0.16 & 0.67 & -0.71 & 0.47 & 0.77 & 0.78 & 0.81 & 0.42 & 0.5 & 0.52 & 1 \\
\hline
\end{tabular}


both marine and land sources and the contribution from land sources were substantially higher than marine sources. The rest of EF's calculated from both equations 3 and 4 are too high and indicate they are mainly from anthropogenic sources.

\section{Correlation Analysis}

Another method that has been used by some authors to identify the sources of ions found in sampled rain waters was correlation analysis. The same procedure was followed in this study and the

Table 6: Varimax-rotated factor matrix of rainwater samples in Tehran (a) Aghdasieh station (b) Mehrabad station

\begin{tabular}{|c|c|c|c|c|c|}
\hline \multicolumn{6}{|c|}{ (a) Aghdasieh } \\
\hline $\mathrm{PH}$ & 0.50 & 0.20 & 0.7 & 0.4 & 0.953 \\
\hline $\mathrm{HCO}_{3}^{-}$ & 0.09 & 0.54 & 0.77 & 0.04 & 0.907 \\
\hline $\mathrm{F}^{-}$ & 0.03 & 0.95 & 0.10 & 0.24 & 0.981 \\
\hline $\mathrm{Cl}^{-}$ & 0.89 & 0.32 & 0.06 & 0.01 & 0.903 \\
\hline $\mathrm{Br}$ & -0.57 & -0.36 & 0.14 & -0.24 & 0.537 \\
\hline $\mathrm{NO}_{2}^{-}$ & -0.02 & 0.96 & -0.23 & 0.01 & 0.992 \\
\hline $\mathrm{NO}_{3}^{2}$ & 0.96 & -0.14 & 0.009 & 0.08 & 0.960 \\
\hline $\mathrm{SO}_{4}^{2-}$ & 0.8 & 0.09 & 0.08 & 0.56 & 0.970 \\
\hline $\mathrm{Na}^{+}$ & 0.04 & -0.11 & 0.08 & 0.94 & 0.923 \\
\hline $\mathrm{Mg}^{2+}$ & -0.11 & 0.48 & -0.86 & -0.004 & 0.993 \\
\hline $\mathrm{Ca}^{2+}$ & 0.85 & -0.26 & 0.40 & 0.09 & 0.981 \\
\hline $\mathrm{NH}_{4}^{+}$ & -0.03 & -0.03 & -0.73 & 0.64 & 0.945 \\
\hline $\mathrm{K}^{+}{ }^{4}$ & 0.50 & -0.08 & -0.04 & 0.82 & 0.952 \\
\hline $\begin{array}{l}\% \text { variance } \\
\text { category }\end{array}$ & $\begin{array}{c}30.49 \\
\text { Anthropogenic } \\
\text { \& soil }\end{array}$ & $\begin{array}{c}21.35 \\
\text { Secondary }\end{array}$ & $\begin{array}{c}20.32 \\
\text { Neutralization }\end{array}$ & $\begin{array}{l}20.11 \\
\text { Natural }\end{array}$ & \\
\hline
\end{tabular}

\section{(b)Mehrabad}

\begin{tabular}{lcccc} 
& Factor1 & Factor2 & Factor3 & Communality \\
\hline $\mathrm{PH}$ & 0.9 & 0.07 & 0.07 & 0.831 \\
$\mathrm{HCO}_{3}{ }^{-}$ & 0.85 & -0.1 & -0.19 & 0.779 \\
$\mathrm{~F}^{-}$ & -0.09 & 0.93 & -0.22 & 0.932 \\
$\mathrm{Cl}^{-}$ & 0.89 & 0.25 & 0.21 & 0.919 \\
$\mathrm{Br}$ & -0.26 & -0.51 & -0.41 & 0.506 \\
$\mathrm{NO}_{2}^{-}$ & 0.09 & 0.98 & 0.06 & 0.977 \\
$\mathrm{NO}_{3}^{-}$ & 0.48 & 0.72 & 0.38 & 0.904 \\
$\mathrm{SO}_{4}^{2-}$ & 0.36 & -0.1 & 0.88 & 0.923 \\
$\mathrm{Na}^{+}$ & -0.005 & 0.07 & 0.95 & 0.910 \\
$\mathrm{Mg}^{2+}$ & -0.20 & 0.87 & 0.25 & 0.870 \\
$\mathrm{Ca}^{2+}$ & 0.96 & -0.07 & 0.20 & 0.974 \\
$\mathrm{NH}_{4}^{+}$ & -0.4 & 0.14 & 0.83 & 0.876 \\
$\mathrm{~K}^{+}$ & 0.41 & 0.39 & 0.79 & 0.970 \\
$\%$ variance & 31.69 & 28.24 & 27.53 & \\
$\mathrm{Category}^{-}$ & Neutralization & Anthropogenic & Secondary & \\
\hline
\end{tabular}


results are shown in Tables $5 \mathrm{a}$ and b. At Aghdasieh, the correlation coefficients range between 0.939 for nitrite and fluoride to 0.695 for $\mathrm{pH}$ and sulfate. Significant test of correlation coefficients showed that ions with anthropogenic origin are well correlated with each other. The same conclusions could be made for ions with natural origin. For example, the correlation coefficient between magnesium and bicarbonate is -0.823 in which all of them mainly come from natural sources. At Mehrabad station, again the highest observed significant correlation coefficient belongs to fluoride and nitrite by 0.909 and the lowest belongs to bicarbonate and $\mathrm{pH}$ by 0.718 .

$\mathrm{NH}_{4} \mathrm{~F}, \mathrm{NH}_{4} \mathrm{Cl}, \mathrm{NH}_{4} \mathrm{NO}_{3}, \mathrm{NH}_{4} \mathrm{HSO}_{4}, \mathrm{NH}_{4}\left(\mathrm{SO}_{4}\right)_{2}$ and $\mathrm{NH}_{4} \mathrm{NO}_{2}$ are common components of atmospheric aerosols $^{30 ; 31 ; 9}$. All of them undergo reversible exchanges between gas and particle phase ${ }^{32 ;} 33$; ${ }^{34}$. The results of correlation analysis suggest that chemical reactions among emitted pollutants from both natural and anthropogenic sources resulted in the formation of secondary pollutants. Some of them like ammonium chloride and sodium nitrate are hygroscopic materials. The latter substances may also react with each other to produce $\mathrm{NaCl}, \mathrm{N}_{2}$ and $2 \mathrm{H}_{2} \mathrm{O}$ in which the $\mathrm{NaCl}$, is again an efficient hygroscopic substance. Solubility of chalk in acids may be regarded as the main reason for good observed correlation between calcium, sulfate and calcium, nitrate ions $\left(\mathrm{CaCO}_{3}+\mathrm{H}_{2} \mathrm{SO}_{4}->\mathrm{CaSO}_{4}+\right.$ $\mathrm{H}_{2} \mathrm{O}+\mathrm{CO}_{2} ; \mathrm{CaCO}_{3}+2 \mathrm{HNO}_{3} \rightarrow \mathrm{Ca}\left(\mathrm{NO}_{3}\right)_{2}+\mathrm{CO}_{2}$ $+\mathrm{H}_{2} \mathrm{O}$ ). Significant correlation between calcium and $\mathrm{pH}$ accompanied with the above results may be interpreted as the main role of calcium cation played in neutralization of acids in sampled rain waters. An astonishing result of the correlation study was its smallness between $\mathrm{Na}^{+}$and $\mathrm{Cl}^{-}$for Aghdasieh samples and it's relatively larger but negative value for Mehrabad samples. This result may be interpreted as an indicator that $\mathrm{NaCl}$ was not the main supplier of those cation and anion in sampled rain waters. Another interesting result is the observed high correlation between two sodium and potassium cations. Since both of them belong to the same group of substances in Mandeleev's periodic table of elements and both are highly reactive and their main source is soil, interpreting the observed correlation is not that simple. However, high observed correlation between potassium and sulfate at both stations and potassium and nitrate at Mehrabad may be related to the existence of crop fields around Tehran and use of the chemical fertilizers. The observed high and positive correlation between sulfate and $\mathrm{PH}$ in Aghdasieh station may be related to the soil structure in the north eastern part of Tehran which has a great amount of lime and calcium sulfate. The high but negative observed correlation between magnesium and bicarbonate in Aghdasieh may be designated to the reaction between two $\mathrm{Mg}^{2+}$ and $\mathrm{HCO}_{3}{ }^{-}$which result in the formation of $\mathrm{MgCO}_{3}$. The other observed correlations among anions and cations are well in agreement with the results of other authors.

\section{Principal Component Analysis}

To use Principal component analysis method in identification of sources, varimax-rotated factor was calculated by means of SPSS software. Results are shown in Tables 6a and b for Aghdasieh and Mehrabad stations. For Aghdasieh station, four principal components were identified. Factor 1, with total variance of 30.49 , encompasses nitrate, chloride, calcium and sulfate. Thus this factor represented the mixed sources of anthropogenic and crust sources. The second group, Factor 2 with total variance of 21.35 encompasses fluoride and nitrite that both are mainly from anthropogenic sources implying a secondary source. Bicarbonates and $\mathrm{pH}$ 's are the main contributor to the third group of principal component known as Factor 3, with total variance of 20.32. It could be a close relationship between bicarbonate, as an effective acid neutralizer and higher measured pH's. The main contributors in the fourth group, Factor4, are sodium and potassium cations that are mainly from natural resources. The same analysis for Mehrabad samples led to the identification of three groups of principal components that are titled Factor 1, Factor 2, and Factor 3. Factor 1 , with total variance of 31.69 , encompasses $\mathrm{pH}$, chloride, calcium and bicarbonate as implying acid neutralization. The second group, Factor 2, with total variance of 28.24 encompasses fluoride, nitrate, nitrite and magnesium all of which represent the mixed sources of anthropogenic and crust sources. The third group, Factor 3, with total variance of 27.53 encompasses sulfate, ammonium and sodium 
all of which imply a secondary source. In total, the anthropogenic pollutants, secondary pollutants, sea salt and crustal minerals were the main sources of those ions in rainwater in Tehran.

\section{CONCLUSION}

The Study of chemistry of precipitation over Tehran indicated that major anions were $\mathrm{HCO}_{3}^{-}$ , $\mathrm{S}_{4}^{0_{4}^{2-}}$ and ${ }^{\mathrm{NO}_{3}^{-}}$, and major cations were $\mathrm{Ca}^{2+}$, $\mathrm{Na}^{+}$and $\mathrm{Mg}^{2+}$. Concentration of all anions and cations were higher in Mehrabad samples than Aghdasieh ones. In both stations, the rainwater was typically alkaline as the $\mathrm{pH}$ value ranged from 4.6 to 8.1 with a volumeweighted mean value of 6.3 . Acidity of rain waters was higher in Mehrabad samples (with minimum amount of 4.6). Observed higher acidity in Mehrabad may be attributed to the existence of factories, nearby passenger terminal, busier traffic condition(s) and more importantly local atmospheric circulation. In both stations, the alkaline , $\mathrm{Ca}, \mathrm{Mg}$ cations and Bicarbonate anion acted as acid neutralizers and buffered the acidity of rain. This is due to the fact that the soils in and around the city of Tehran are, $\mathrm{CaSO}_{4}$, $\mathrm{CaCO}_{3}$, and $\mathrm{MgCO}_{3}$ rich soils. Source identification has been done with several methods, indicated that $\mathrm{SO}_{4}, \mathrm{NO}_{3}, \mathrm{NO}_{2}, \mathrm{~F}, \mathrm{Br}$ and part of $\mathrm{HCO}_{3}, \mathrm{Cl}$ and $\mathrm{NH}_{4}$ came from anthropogenic sources, where, $\mathrm{Ca}, \mathrm{Mg}$, $\mathrm{K}, \mathrm{Na}$, and the most part of $\mathrm{HCO} 3$ originated from natural sources (dust). There were also some secondary particles, namely $\mathrm{NH}_{4} \mathrm{NO}_{2}, \mathrm{NH}_{4} \mathrm{~F}, \mathrm{NH}_{4}$ $\mathrm{Cl}, \mathrm{NH}_{4} \mathrm{NO}_{3}, \mathrm{NH}_{4} \mathrm{HSO}_{4}, \mathrm{NH}_{4}\left(\mathrm{SO}_{4}\right)^{2}$, in sampled rain waters. Due to urbanization, increase of usage of water resources and substantial reduction in precipitation amount, the main particulate matters found over Tehran were dust particles. Increase in atmospheric dust, especially in the spring, are quite clear from the values of total alkalinity, EC, $\mathrm{pH}$, total hardness and TDS. Factories around Tehran, oil refineries, fossil fuels, agricultural activities, Qom salt lake and great desert in south of Tehran may be counted as the main sources of found materials in sampled rain waters. Consequently, it could be concluded that the chemistry of precipitation over Tehran influenced by short, medium and long distance sources.

\section{REFERENCE}

1. Likens, G. E., W. C. Keene, J. M. Miller, and J. N. Galloway. J. Geophys. 1987, 92, 299314.

2. Esmaili Srai, A. Ir. of Iran Meteorological Organization. 1991, 1-200.

3. Esmaili Srai, A. Ir. of Iran Meteorological Organization. 1997, 1-70.

4. Kulshrestha, U.C., Sarkar, A.K., Srivastava, S.S., Parashar, D.C. Water, Air and Soil Pollution. 1995, 85, 2137-2142.

5. Kulshrestha, U.C., Sarkar, A.K., Srivastava, S.S., Parashar, D.C.Atmos. Environ. 1996, 37, 3019-3026.

6. Zunckel, M., Saizar, C., Zarauz, J. Atmos. Environ. 2003, 37, 1601-1611.

7. Hu, G.P., Balasubramanian, R., Wu, C.D. Chemosphere 2003, 51, 747-755.

8. Tang, A., Zhuang, G., Wang, Y., Yuan, H., Sun, Y. Atmos. Environ. 2005, 39, 3397-3406.

9. Zhang, M., Wang, S., Wu, F., Yuan, X., Zhang, Y. Atmos. Res. 2007, 84, 311-322.

10. Cao, Y.Z., Wang, Sh., Zhang, G., Luo, J., Lu, Sh. Atmos. Environ. 2009, 94, 462-469.
11. Cerqueira, M.R.FM, Pinto, M.F.P., Derossi, I.N., Esteves, W.T., Santos, M.D.R., Matos, M.A.C., Lowinsohn, D., Matos, R.C. Atmospheric Pollution Research. 2014, 5, 253261.

12. Park, S.,; Seo, B., Lee, G., Kahng, S., Jang, W. Atmosphere. 2015, 6, 732-750.

13. Rahn, K.A. Atmos. Environ. 1967, 10, 597601.

14. Keene,W.C., Pszenny, A.P., Galloway, J.N., Hawley, M.E. J. Geophys. 1986, 91, 66476658.

15. Vermette, S.J., Drake, J.J., Landsberger, S. Water Air Soil Pollut. 1988, 38, 37-53.

16. Ahmed, A.F.M., Singh, P.R., Elmubarak, A.H. Atmos. Environ. 1990, 24, 2927-2934.

17. Safai, P.D., Rao, P.S.P., Momin, G.A., Ali, K., Chate, D.M., Praveen, P.S. Atmos. Environ. 2004, 38, 1705-1714.

18. Budhavant, K.B., Rao, P.S.P., Safai, P.D., Granat, L., Rodhe, H. Atmos. Environ. 2014, 88, 59-65.

19. Rahn, K. A. A compilation. I. Extern. 1975, 4, 286-313. 
20. Taylor, S.R. Cosmochim. Acta 1964, 28, 1273-1285.

21. Huang, K., Zhuang, G., Xu, Ch., Wang, Y., Tang, A. Atmos. 2008, 89, 149-160.

22. Sorooshian, A., Shingler, T., Harpold, A., Feagles, C.W., Meixner, T., Brooks, P.H. Atmos. Chem. Phys., 2013, 13, 8615-8662.

23. Chune, S., Xueliang, D., Yuanjian, Y., Xiangrong, H., Biwen. W. ADV. IN ATMOS 2014, 31, 1157-1166.

24. Jain, M., Kulshrestha, U., Sarkar, A., Parashar, D. Atmospheric Environment 2000, 34, 5129-5137.

25. Pruppacher, H.R., and J.D. Klett. Microphysics of Clouds and Precipitation. 1997, 954-960.

26. Levin, Z., E. Ganor, and V. Gladstein. J. Appl. Meteor., 1996, 35, 1511-1523.

27. Trochkine, D., Y. Iwasaka, A. Matsuki, M.
Yamada, Y.S. Kim, T. Nagatani, D. Zhang, G.Y.Shi, and Z. Shen. J. Geophys. 2003, 108, 8642-8649.

28. Li, W.J., Shao, L.Y. Atmos. Chem. Phys. 2009, 9, 1863-1871

29. Yang, F., Tan, J., Shi, Z.B., Cai, Y., He, K., Ma, Y., Duan, F., Okuda, T., Tanaka, S., Chen, G. Atmos. Chem. Phys. 2012, 12, 2025-2035.

30. Bridgman, H. Global Air Pollution. Wiley, London. 1994, 261.

31. Seinfield, J.H. Wiley Interscience, New York. 1986, 219.

32. Pio, C.A. and Harrison, R.M. Atmos. Environ. 1987, 21, 1243-1246.

33. Matsumoto, K. and Tanaka H. Atmos. Environ. 1996, 30, 639-648.

34. Du, H., Kong, L., Cheng, T., Chen, J.,Yang, X., Zhang, R., Han, Z., Yan, Z., Ma, Y. Aerosol and Air Quality Research. 2010, 10, 589-59 